\title{
ACCELERATION AND STRENGTHENING OF SHARIA FINANCIAL INCLUSION THROUGH MERGING SHARIA BANKING IN INDONESIA
}

\author{
Syarifuddin Syarifuddin ${ }^{\text {a }}$ \\ Ega Rusanti ${ }^{\mathbf{b}}$ \\ Mega Octaviany ${ }^{c}$ \\ Abdurrahman Mansyur ${ }^{d}$ \\ a,b Department Study of Islamic Economics, Alauddin State Islamic University of Makassar \\ 'Department Study of Sharia Economy, Gunadarma University \\ dDepartment of Islamic Contemporary Studies Focus on Islamic Economics Student, \\ University Sultan Zainal Abidin Malaysia

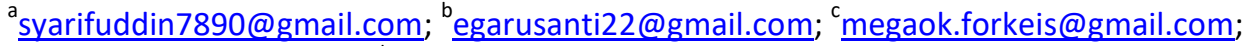 \\ dabdurrahmanmansyur@gmail.com
}

ARTICLE HISTORY
Received:
25 January 2021
Revised
9 April 2021
Accepted:
31 May 2021
Online available:
30 June 2021
Keywords:
Sharia Financial Inclusion,
Sharia Financial
Strengthening,
Strategy of Acceleration,
Mergers,
Sharia Banking.
*Correspondence:
Name:
Syarifuddin
E-mail:
syarifuddin7890@gmail.com

\section{ARTICLE HISTORY}

Revised

Online available:

Keywords:

Inclusion

Strategy of Acceleration,

Mergers,

Sharia Banking.

*Correspondence:

syarifuddin7890@gmail.com

\begin{abstract}
Islamic banking in Indonesia is slowly experiencing significant developments both in terms of number of assets and its financial performance. On the other hand, the market share was only able to grow by 6.18 percent with grow rate less than 5 percent. Therefore, one of the strategies to increase and accelerate the growth of Islamic banking is through a merger. The purpose of this study is to provide an overview of the potential development of Islamic banking after the merger as an effort to strengthen the inclusion and acceleration of Islamic finance in Indonesia. The method used is in the form of a systematic analysis review by collecting various secondary data and then conducting a quality assessment to obtain in-depth research objectives. The results found through content analysis indicate that the merger strategy provided added value to the banking industry through greater market expansion, increased cost efficiency, financial performance, and lowering prices, to meet the public need for sharia-based financial services. Through a merger strategy, Islamic banking is able to become a new pillar of national economic strength and encourage Indonesia to become the center of the world on Islamic finance.
\end{abstract}

\section{INTRODUCTION}

Islamic banking exists as an alternative as well as a solution for usury-based banks. Islamic banks have established their position in the world, especially in Muslim countries and have grown rapidly in the last few decade (Alharbi, 2015). The Islamic bank initially appeared in 1963 as a pilot project which was established in small rural town of Mit Ghamr, Egypt. After that, the second Islamic bank was established in Pakistan in 1965 in the form of a cooperative bank. The development of Islamic banks in the world continued to receive appreciation until it peaked in the mid-1970s marked by the establishment of the Islamic Development Bank (IDB) on 20 October 1975 which functioned as a multilateral international Islamic financial institution 
(Fahim et al., 2017). The establishment of IDB contributed to the formation of larger Islamic banks in various countries such as Dubai Islamic Bank in Dubai (March 1975), Kuwait Finance House in Kuwait (1977) and Faisal Islamic Bank in Egypt and Sudan (1977) (Ascarya \& Yumanita, 2005). To date, there are more than 200 Islamic banks and financial institutions operating in 70 countries in the world, both Muslim and non-Muslim countries with portfolio around \$200 billion (Islamic Finance Country Index, 2020) .

In Indonesia, the development of Islamic banking is a manifestation of the people who desperately need a healthy financial system that provide banking and other financial services that comply with sharia standards (Syukron, 2013). The presence of Islamic banking in Indonesia began with the establishment of Bank Muamalat in 1991. This bank was spearheaded by the Indonesian Ulema Council, ICMI or the Indonesian Muslim Intellectual Association, the Government and Muslim entrepreneurs. However, this bank is still less popular and has a stagnant performance. But after its performance was considered to be resistant during the economic crisis and reformation, Bank Muamalat gaining more attention and followed by the establishment of other Islamic banks (Marimin \& Romdhoni, 2017).

Based on data from the Financial Services Authority (OJK), until 2019, there were 289 Islamic banks, consisting of 14 Islamic Commercial Banks (BUS), 164 Islamic Rural Banks (BPRS) and 20 Sharia Business Units (UUS) (Financial Service Authority, 2017). This development continually occur, one of which is influenced by regulations that encourage separation between conventional and Islamic commercial banks in 2008. With this regulation, it is estimated that by 2023 all UUS including Regional Banks must spin off or separate between business entities and became a subsidiary of Islamic banking (Marimin \& Romdhoni, 2017).

Table 1

Development of Islamic Bank in Indonesia

\begin{tabular}{cccccc}
\hline $\begin{array}{c}\text { Banking } \\
\text { Industry }\end{array}$ & $\begin{array}{c}\text { Number of } \\
\text { Institutions }\end{array}$ & $\begin{array}{c}\text { Number of } \\
\text { Offices }\end{array}$ & $\begin{array}{c}\text { Total Assets } \\
\text { (In Trillion } \\
\text { Rupiah) }\end{array}$ & $\begin{array}{c}\text { Financing } \\
\text { Provided } \\
\text { (In Trillion } \\
\text { Rupiah) }\end{array}$ & $\begin{array}{c}\text { Third Party } \\
\text { Funds } \\
\text { (In Trillion } \\
\text { Rupiah) }\end{array}$ \\
\hline BUS & 14 & 1.919 & 350.36 & 225.15 & 288.98 \\
UUS & 20 & 381 & 174.20 & 130.04 & 127.58 \\
BPRS & 164 & 617 & 13.76 & 9.94 & 8.73 \\
Total & 198 & 2.917 & 538.32 & 265.13 & 425.29 \\
\hline
\end{tabular}

Source: Financial Service Authority (2017)

Apart from the number of units, the growing assets of Islamic banking is considered to have increased following the dual banking system policy. This rapid growth was driven by several factors, such as the increase in the number of branch offices expanding the market to the regions, as well as the stable and healthy performance of Islamic banks amidst economic shocks with a profit sharing system (Hendriana, 2012). Until 2019, Islamic banking assets showed positive growth, even though it was considered to have slowed down compared to previous year. In the last three years, Islamic banking assets are still maintained in the double digit category with 356,330 billion rupiah as of June 2020 (Financial Service Authority, 2019). 
Although the value of asset show increasing year on year, yet the growth rate is experiencing a downward trend, so the ratio of Islamic banking assets to the national banking industry is still low with less than $5 \%$ per year (Komite Nasional Keuangan Syariah, 2020). In addition, the market share of Islamic banking in Indonesia still very low, which is only $6.18 \%$, which means that $93.82 \%$ of the national banking market is still held firmly by conventional banks. These $6.18 \%$ consisted of $65.08 \%$ BUS, BPRS $2.56 \%$ while UUS reach $32.36 \%$. Meanwhile, from the demand side of Islamic financial service products, only have a financial inclusion level of $9.1 \%$ (Bank Indonesia, 2018).

Some of these facts in recent times have encouraged the emergence of a discourse on the merger of Islamic banks, especially state-owned Islamic banks (SOE). Currently, there are three state-owned sharia banks, namely: PT Bank Syariah Mandiri, PT BNI Syariah, PT BRI Syariah and one sharia business unit which is PT Bank Tabungan Negara Tbk (BTN). The fundamental reason for this merger is the desire to have a sharia bank that is large, strong, and efficient with large assets and financing capabilities, so it is expected to make a large contribution to the national economy (Nizar \& Nasir, 2016a). The rumors of a business merger finally met clarity with the finalization of the merger plan for three Islamic state-owned banks officially named Bank Syariah Indonesia with the stock code BRIS on December 11, 2020 (CNBC Indonesia, 2020).

This business merger policy aims to encourage the advancement of Islamic banking. Sharia commercial banks (consolidated results) will get stronger as the company gets bigger. This state-owned sharia bank will have more authority than the sharia bank prior to consolidation. This is due to the capital owned by the bank is getting bigger. It can be seen that there are many benefits that will arise if consolidation is carried out (Gupitasari et al., 2016).

However, the Meger and Acquisition (M\&A) policy has generated new debates regarding the benefits of increased added value. This claim emerges based on much foregoing research that has provided a negative narrative on this decision in countries that have conducted prior M\&A. As research conducted by Calomiris and Karceski (2000) that obtained four important findings from nine meger bank cases that occurred in the United States, namely: 1) overall, this merger process formed an added value for the banking industry; 2 ) the behavior of bank management that is about to be merged will cause unnecessary increases in costs, such as promotions and salaries which at the time before the merger had a strategic position; 3) several merged banks experienced defaults due to drastic drop in revenue during the consolidation period; and 4) income synergy occurs but not with cost efficiency.

This merger policy also affects to small borrowing customers. They are often neglected in merger considerations even though there is usually a decline in interest rates after the merger has be done (Montoriol-Gariga, 2008). In addition, for banks that have branches with overlapping placements, it is also a new problem in conducting a merger (Jayaratne \& Strahan, 1997). Research conducted by Kimie and

Published by University of Airlangga.

This is an open access article under the CC BY license (https://creativecommons.org/licenses/by-nc-sa/4.0/) 
Takatoshi (2008) which refers to the case of meger banks in Japan found the results if this merger will only create weak banks and in some cases, the merger will only cause a worsening "distance to default".

Therefore, to see the effectiveness of this policy, many things must be done, including the calculation of the profit and loss probability of transactions resulting from the merger between banks. Many banks still not clear about their merger partners, so they need an open approach and transparency regarding their wealth and financial conditions. So each of those banks that will conduct the merger are able to see how big the opportunity for the merger, and how the policy able to accelerate and strengthen the growth of Islamic finance in Indonesia. Moreover, Indonesia is aggressively pursuing the growth of international standard sharia banking industry and is projected to become the center of the world Islamic economy by 2030 , so this policy becomes very crucial to be discussed and studied deeply.

\section{LITERATURE REVIEW}

\section{Development of Islamic Banks in Indonesia}

The development of Islamic banking in Indonesia cannot be separated from the presence or absence of support from the government, one of which is reflected in the banking policies issued by the government (Zubair, 2008). The beginning of the journey of Islamic banking in Indonesia began with the establishment of Bank Muamalat Indonesia (BMI) in 1992. BMI is not only the first Islamic bank but also an economic institution that has a working system according to sharia. Moreover, BMI is called a symbol of the revival of the Islamic economic system in Indonesia (Syukron, 2013).

However, formally the existence of Islamic banking in Indonesia in 1992 was also marked by the enactment of UU No. 7 of 1992 concerning Banking. The regulation has actually not been able to provide a strong legal basis for the development of Islamic banks because it has not included explicitly and in detail the words "sharia principles" and only in the form of the term "profit-sharing" (Hendriana, 2012). The definition of profit sharing as referred to in the Law is not yet in accordance with the meaning that includes Islamic banking, which is broader than just profit sharing (Sari et al., 2013). In the absence of articles discussing Islamic banking in the Act, in 1998 it was amended into Law No. 10 of 1998. This law then provides an explicit provision that banks can carry out their operations based on sharia. Simultaneously with the law, banking law policies in Indonesia were enforced by adopting a dual banking system. This means that every conventional commercial bank is given the opportunity to provide sharia services through an Islamic window mechanism on the condition that they first have to establish a Sharia Business Unit (UUS) (Zubair, 2008). After the implementation of this policy, conventional banks formed UUS and provided sharia services to their customers. Those are the milestone to accelerate the development of Islamic banks, although this law is not sufficient to provide a stronger legal umbrella to encourage the growth of Islamic banking and the development of Islamic products in a more juridical manner (Suhendro, 2018). 
The sharia banking industry continues to experience developments both in terms of office networks as well as its financial performance as a form of effort to meet the public's needs for sharia-based banking products and services in Indonesia. Although the current national economic conditions tend to weaken, the growth of Islamic banking continues to stretch. Based on the Indonesian Sharia Financial Development Report published by the Financial Services Authority (OJK) until December 2019, there were 14 Islamic Commercial Banks in Indonesia with a total of 1.919 offices (Financial Service Authority, 2019).

The rapid development of the banking industry from the perspective of the office network is the result of increased public needs and the desire of banks to provide banking services in accordance with sharia principles. 2019 is still a period of consolidation for Islamic banks. Even so, in the midst of an economy that is still reluctant to stretch, Islamic banking is still recording growth, both BUS (Islamic commercial banks) and UUS (sharia business units). Islamic banking assets in 2019 still showed positive growth, even though it experienced a slowdown compared to the previous year. In the last three years, the growth of Islamic banking assets remained constant at double digits, with a market share not less than $6.18 \%$ of the national banking industry, slightly increase compared to the previous year which was $5.96 \%$. Both BUS, UUS, and BPRS have shown positive trend. The growth in these assets was accompanied by an increase in profit, even though it was very small. In December 2018, the profit earned was 6.93 trillion rupiah, up to 7,029 trillion rupiah or grew by only 1.4 percent. Of the 34 Islamic banks (14 BUS and 20 UUS), there are 30 banks that have a Conventional Commercial Bank as parent company (Financial Service Authority, 2019). One of the OJK's strategic programs in the 2015-2019 Indonesian Sharia Banking Roadmap is to increase the commitment of the parent Islamic bank through increasing capital and business scale, improving efficiency through optimizing the parent role, and developing Islamic banking services to reach a minimum share of $10 \%$ of the parent BUK assets. Until the end of 2019 , there were eight UUSs that had asset shares exceeding $10 \%$ of the assets of their parent Conventional Commercial Bank (BUK) (Financial Service Authority, 2017).

Stimulously, Islamic banks continue to have a positive influence on the national economy. Apart from that, Islamic banking also continues to improve in order to improve the halalness of its products and services. Both in the form of financing and savings needs. The development of the halal economy will also play a major role in Islamic banking in supporting healthier economic planning (Komite Nasional Keuangan Syariah, 2019).

\section{Merger in the Banking Industry in Indonesia}

Bank is an institution engaged in financial traffic activities. Therefore, all actions taken by banks must have a clear legal basis as stipulated in the law. One of the banking strategies in improving its quality is by restructuring the company. This strategy is better known as a merger (incorporation), consolidation (fusion), and

Published by University of Airlangga.

This is an open access article under the CC BY license (https://creativecommons.org/licenses/by-nc-sa/4.0/) 
acquisition (takeover) (Ascarya \& Yumanita, 2005). This strategy is clear and legalized through Law No. 40 of 2007 concerning limited liability companies. A merger is a combination of two or more entities through a purchase acquisition or pooling of interests, this differs from consolidation because no new entity is created from the merger (Gupitasari et al., 2016). The motives behind mergers and acquisitions are economies of scale, economic coverage, increasing market share and revenue, taxation, synergy, geography, and other diversification. For these reasons the banks merged $r$ or became the target of bank acquisitions (Calomiris \& Karceski, 2000). This merger will form a new company by bringing together all the assets and liabilities of each company (Carletti et al., 2007).

According to Gitman and Zuter (2011), mergers can be classified into four types, namely: 1) horizontal merger, a merger conducted by two or more companies that have the same field; 2 ) vertical merger, is a merger that occurs when a company acquires a company which is its customer or supplier; 3 ) conglomerate merger, is a merger carried out by two or more companies that do not have a business connection or in the same field (unrelated business); and 4) congeneric merger, which is a merger that occurs when two or more companies join forces which have the same field but have no relationship with the customer or supplier.

Merger is nothing new in Indonesia's banking industry. Both national and private banks have conducted mergers with the motive of strengthening the company (Ismariyah, 2007). In 1999, there was a merger by four state-owned banks, namely the Bank Export-Import Indonesia, Bank Dagang Negara, Bank Pembangunan Indonesia, and Bank Bumi Daya which switched to PT. Bank Mandiri. Meanwhile, in 2002 the merger was also carried out by five private banks namely Bank Universal, Bank Express, Bank Bali, Bank Patriot, and Bank Artamendia which were merged into Bank Permata. And in 2004 a merger was carried out by Bank Danpac, Bank Pikko, and Bank CIC Internasional decided to merge into Bank Century (Prihartono, 2018).

Meanwhile at the end of 2020, for the first time, the national Islamic banking merged by incorporating PT Bank BRI SyariahTbk (BRIS), PT Bank Syariah Mandiri (BSM), and PT Bank BNI Syariah (BNIS) to become Bank Syariah Indonesia with stock code (BRIS). The composition of shareholders in the three combined banks is PT Bank Mandiri 51.2 percent, BNI 25 percent, BBRI 17.4 percent, DPLK BRI - Sharia 2 percent. and public 4.4 percent (CNBC Indonesia, 2020) The decision to merge Islamic banking was motivated by various factors, including the motive to strengthen Islamic banking as a financial institution that is expected to be able to contribute to the national economy more significantly. In addition, this decree officially combines human and financial resources, information systems, and technology as well as other financial and products in order to provide comprehensive services in the banking industry in accordance with the sharia system.

This merger and acquisition are considered to be successful in Indonesia by looking at the track record of top banks formed from the merger such as Bank Mandiri, Bank Permata, and Bank Danamon (Nizar \& Nasir, 2016a). This merger decision will have a positive impact on the economy because it is considered to increase public confidence in using banking products and services such as savings, 
current accounts, and time deposits (Komite Nasional Keuangan Syariah, 2019). In addition, the success of this merger has also occurred in big countries like America which have succeeded in providing both macro and micro impacts on their economies by considering three main aspects. These three aspects consist of: 1) competition and concentration, this merger will encourage efficiency and increase performance; 2 ) health and safety aspects, this emphasizes that the merged company must become healthier and safer as an effort to improve and strengthen the company's composition; and 3) aspects of service to the community, it is hoped that the merger will not reduce banking services to the community but be more capable of increasing and expanding geographically and the quality of users of its products (Brewer et al., 2000).

\section{Advantages of Bank Mergers}

Since the establishment of the first Islamic bank in Indonesia, to date, many steps have been taken to improve the performance and market share of Islamic banking. Moreover, the mission is to become a country as the center of Islamic finance in the world. It is not impossible if Indonesia is able to achieve this, especially with the potential as a country with the largest Muslim population in the world (Prihartono, 2018). Therefore, various strategies are needed in an effort to support the achievement of these big goals. For the sake of realizing healthy banking with strong capital. One of the most popular policies taken to create healthy banking with strong capital at that time was a merger (Bank Indonesia, 2018)

Mergers can increase efficiency by enabling banks to achieve economies of scale or by achieving a combined output that is more profitable than before. In addition, bank mergers can generate efficient profits by changing the input-output mix in a way that optimizes costs and revenues (Montoriol-Gariga, 2008). In addition, in several studies, it is known that financial performance improves in the long term after the merger (Ahdizia et al., 2018). Merger company stock prices also increased after the merger agreement, with the financial health condition of the merger companies describing an identical or better situation (Nizar \& Nasir, 2016a). This illustrates that there is a positive influence on financial performance as a result of post-merger organizational restructuring.

In terms of banking products, the merger has also had a positive impact on prices and offers for banking savings products. The deposit market is a natural laboratory for studying the effects of mergers for three reasons. First, competition at the local level, allows the examination of merged share prices in markets with different characteristics, while maintaining constant industry. Second, the presence of large local players and the presence of barriers to entry to the local savings market (branch opening cost) imply that mergers can change competitive conditions. Third, bank deposits are a highly standardized product (some of the main characteristics are stipulated by law), so they can be compared periodically over time and between different banks (Kemal, 2011).

Published by University of Airlangga.

This is an open access article under the CC BY license (https://creativecommons.org/licenses/by-nc-sa/4.0/) 


\section{RESEARCH METHODS}

This research is a literature study using the systematic literature review (SLR) method. Systematic literature review is a term that refers to a particular research or research methodology and development carried out to collect and evaluate research related to a particular focus topic (Balqis \& Sahar, 2019). The purpose of this research is to provide disclosure and assessment results regarding the effect of the merger as a strategy to accelerate and strengthen the inclusiveness of Islamic banking through a business merger strategy. The data used in this research comes from the results of research that have been conducted and published in national and international online journals. In conducting this research, the researchers conducted a search for research journals published on the internet using search engines such as Research Gate, Garuda, and Scholar with keywords: mergers, Islamic banking, accelerated Islamic finance, and Islamic financial inclusion.

The data collection process is carried out by filtering based on the criteria determined by the author of each journal taken. The criteria for journal submissions are as follows:

1. Literature sources are collected based on the suitability of writing keywords, linkages of writing results, and discussion;

2. The strategy for collecting journals is taken from various literatures using accredited journal sites such as Research Gate, Garuda, and Scholar; and

3. Conducting an assessment of the references that have been obtained by determining the quality assessment which consists of:

QA1. Does the reference discuss the concept of a merger in the banking scope?

QA2. Does the reference provide an overview of the changes experienced by banks after the merger?

QA3. Does the reference describe the development strategy of Islamic banking through a merger?

A reference that is considered appropriate as a basic theory and data of this research is when it is able to get at least 2:1 point from a predetermined quality assessment. In this study, the total references collected were 78 journals with a classification of 51 international journals and 19 national journals, nine research reports in the form of published articles and final assignments (minithesis, thesis, and dissertation). After going through the quality assessment process, 35 articles were obtained which were deemed eligible as the main reference and were able to assist in the preparation of research results. The references consist of 23 international journals, eight national journals, and four research reports.

\section{RESULT AND ANALYSIS}

\section{Sharia Bank Merger in Market Expansion Efforts}

In the recent global economy, mergers and acquisitions (M\&A) are increasingly being applied around the world to improve the competitiveness of companies to gain a bigger market (Elnahas et al., 2017). Merger is a combination of two or more entities through a purchase acquisition or pooling of interests, it differs 
from consolidation because no new entity is created from the merger. The motives behind mergers and acquisitions are economies of scale, economic coverage, increasing market share and revenue, taxation, synergy, geography, and other diversification. For these reasons banks have merged or have become targets of bank acquisitions (Goyal \& Joshi, 2011).

This industrial merger occurred mainly because of financial and technological innovations that changed the optimal production function of financial firms. The enabling force is the wave of financial deregulation that is required for banks and other financial services to take full advantage of new production processes and technological advances that are revolutionizing processing to reach a larger market both in terms of geographic and better serviceability (Vallascas \& Hagendorff, 2011). Companies that want rapid growth in market size or share as well as diversification in their product range make it possible to merge to fulfill this, rather than increasing production capacity or internal diversification which are deemed less efficient and require a larger planning volume (Montoriol-Gariga, 2008). Another important advantage behind this kind of merger is that in this process, competition is reduced because the merger removes competitors from the banking industry (Goyal \& Joshi, 2012).

Berger and DeYoung (2001) found that banking organizations undertake significant control over their merger affiliates were able to narrow the gap and the expansion of the post-merger market. This finding is in line with the increasing ability of banks to expand geographically. They also conclude that distance has a negative effect on costs, profits, and managerial control in the banking industry. This is also supported by the unification of information and communication systems that are constantly evolving.

Islamic financial institutions will be benefited from a consolidation or merger in several ways. First, Islamic financial institutions can expand the scope of their products and services. Second, Islamic financial institutions can build a solid infrastructure for new services on both sides. Third, Islamic financial institutions can gain efficiency through diversification and improving management quality. Mergers and acquisitions will have a significant effect on post-long-term performance to control the crisis (Ahdizia et al., 2018). The merger of several sharia business units will be able to strengthen the capital of the sharia bank resulting from the merger. In addition, merger between Islamic business units will make them more ready to compete in the ASEAN economy, even the global economy (Sufian, 2007).

Merger strategies must be encouraged in small, inefficient Islamic banks to be acquired by their more efficient partners, regardless of national borders and the financial system. Then the result of this less efficient merger of Islamic banks can obtain reduced costs from expansion and economies of scale, although these benefits can be offset by increasing the level of efficiency. In order to be able to operate in the global market, Islamic banks must carry out an alliance strategy with other banks. This will also be useful for building bridges between Islamic banks and

Published by University of Airlangga.

This is an open access article under the CC BY license (https://creativecommons.org/licenses/by-nc-sa/4.0/) 
conventional banks that are interested in conducting banking services with Islamic principles.

\section{Merger Strategy in Cost Efficiency Efforts in Islamic Banking}

The issue of mergering syariah bank that combines three largest Islamic banks in Indonesia, namely BNI Syariah, BRI Syariah and Mandiri Syariah is on trending. In particular, this discussion was related to whether a bank merger could increase efficiency or not. Al-Sharkas et al. (2007) in their research on banks in the United States showed that a bank merger can increase efficiency by achieving economies of scale or by achieving a combined output that is more profitable than before. In addition, bank mergers can generate efficiency by changing the input-output mix in a way that optimizes costs and revenues. Efficiency gains usually result from economies of scale implying lower costs or higher revenues. These efficiency gains are then potentially passed on to customers. Examples of cost reduction are reduction of overlapping branches or fixed cost savings.

There are several ways M\&A can increase efficiency. First, large companies resulting from consolidation can gain access to more cost-effective technology or spread their fixed costs over a larger base, thereby reducing average costs (Long, 2015). Efficiency can also be gained from exploiting the economic sphere: the agreement allows the joining forces to enter new markets and cross-sell their products to a wider customer base. Finally, consolidation can improve cost and managerial efficiency (Elnahas et al., 2017).

Increased cost efficiency occurs when banks could manage to costs within efficient limits or banks with best practices (most efficient managed banks) to produce output that is equal to or more than the input price (Clarke \& Salleh, 2011). Previous research has shown that many banks have merged with the aim of increasing efficiency. For example, Berger and Humphrey (1992) have studied fiftyseven US banking mega-mergers from 1981 to 1989. They estimated a neo-classical cost function that allowed them to consider two types of efficiency: economies of scale and cost-efficiency. Berger and Humphrey (1992) came to two main conclusions. First, if the more efficient bank takes over the less efficient one, the merger can yield substantial efficiency gains. Second, merger rates fail to improve cost efficiency. The average efficiency increase was less than a five-point percentage and was not statistically significant. Moreover, because of the diseconomies of scale, the performance of the combined companies actually worsens slightly after the merger, albeit of small effect and not statistically significant. The authors conclude that the diseconomies created by the mega-merger could easily offset the benefits resulting in reduced cost efficiency (Berger \& Humphrey, 1992).

Meanwhile, a study conducted by Berger and DeYoung (2001) found that $58 \%$ of the 348 merger samples resulted in low-cost efficiency. Although part of this advantage was due to mergers involving bankrupt targets (where support from the FDIC may have helped improve bank performance), $61 \%$ of solvent bank purchases also resulted in cost efficiency. In addition, Berger and DeYoung (2001) research results show that mergers from banks of the same size result in insignificant cost 
efficiency. Moreover, bidders who are experienced deal-makers receive a greater efficiency increase.

These findings tentatively suggest that efficiency improvements can be expected from banking mergers although most studies that have compared pre-and post-merger performance have found that potential efficiency gains are seldom materialized (Sherman \& Rupert, 2006). Efficiency improvements may take a long time to occur. While some other efficiencies such as those derived from diversifying risks or brand name benefits may be obtained in the short term, other benefits such as benefits derived from reduced costs or a large part of the economy may take longer to materialize. This may be due to the difficulty in integrating institutions that are broadly different (Al-Sharkas et al., 2007).

The efficiency obtained from the merger may be delayed by several factors. First, cutting costs takes time. In fact, managers of merged companies may wish to restructure (consolidate headquarters and close overlapping branches) incrementally, to minimize adjustment costs and allow time to assess results while plans are implemented (Elnahas et al., 2017). Cost reduction can also be delayed by reluctance to lay off staff, especially in businesses where human resources are important, such as financial services and high-tech industries or by difficulty selling excess capital goods (Karceski et al., 2005).

The research conducted by Yudistira (2004) shows the importance of mergers and acquisitions for small and medium Islamic banks in several samples in increasing cost efficiency and achieving targeted performance through expanding economies of scale (Yudistira, 2004). The increase of economies of scale through mergers is an important variable in determining the efficiency of a post-merger bank. In addition, the merger at Islamic banks shows that if the merger is carried out by a small and medium-sized bank, it will achieve a more optimal economic scale so that it is able to stimulate the desired cost efficiency (Miftah \& Wibowo, 2017). Apart from that, Islamic banking has insufficient resources in minimizing threatening financial risk. Therefore, through a merger strategy, Islamic banking can conduct portfolio diversification and improve financial performance so as to create greater cost efficiency, be better able to handle competition in the financial market more efficiently, and expand the scope of operations (Nizar \& Nasir, 2016b).

\section{Merger in Efforts to Improve Sharia Banking Financial Performance}

Regulatory steps are being taken at both the micro and macro levels to improve the future conditions of various sectors that are threatened under a financial crisis to improve their financial performance (Degryse et al., 2004). To overcome this financial crisis, many mergers and acquisitions were carried out. This increase in mergers and acquisitions will change the entire structure of the financial industry with the aim to make the sector healthy and reducing the risks inherent in the financial industry and improving its financial performance (Haynes \& Thompson, 1999). 
Policymakers must generate a better institutional framework. A better institutional framework will play an important role in increasing the level of bank efficiency even though the banking industry is highly centralized (Brewer et al., 2000). Thus, the merger (or banking consolidation) can become an alternative policy that can be taken by policymakers to strengthen and accelerate the banking industry, especially in Islamic banking. Miftah and Wibowo (2017) state that the merger will contribute to the development of the Indonesian Islamic banking sector by increasing bank efficiency based on savings on consolidation costs and improving financial performance, especially in the face of the crisis.

Several studies have evaluated post-merger performance in the banking industry. This study has generally indexed the performance against several industry standards and then compared the indexed performance before and after the merger. Changes in performance against standards are considered as a result of the merger. Carletti et al. (2008) found that banking consolidation worked well to eliminate the influence of macroeconomic forces, regulatory changes, and other industry-wide phenomena. Meanwhile, Al-Hroot et al. (2020) investigated the effect of mergers and acquisitions on the financial performance of the banking sector in Jordan. The sample size of the study consisted of two bank groups. Secondary data were collected from selected sample financial reports. To analyze data, financial ratios such as ROI, investment appraisal ratios, ROE, and liquid ratios show the negative effect of mergers and acquisitions on financial performance. Furthermore, the study reveals that financial improvements can be achieved in the long term.

The same result was also found by Healy et al. (1992). This study found that there was a strong relationship between post-merger and increased operating cash flow, as well as stock returns on the merger announcement. Meanwhile, Ghosh and Jain (2000) investigated whether corporate mergers improve financial performance. They find that the company's financial performance can improve due to increased debt capacity or from unused debt capacity prior to the merger years. And they found a significantly increased financial impact of the combined companies after the merger.

Several studies have shown that not all banks that enter into merger or acquisition agreements show a significant increase in both performances and return on equity compared to their pre-merger performance. In addition, an extensive analysis was carried out with the same results so that it can be concluded that mergers and acquisitions do not have a clear effect on the profitability of banks in Egypt. They only have a small positive effect on the credit risk aspect. These findings do not support the current financial consolidation and banking reform processes observed in Egypt and provide weak evidence to support their constructive role in increasing bank profitability and restructuring the economy (Zaharias \& Pradipta, 2016).

\section{The Impact of Merger on Market Pricing}

Another strategy that can improve the performance of Islamic banks is a merger (Nizar \& Nasir, 2016b). Merger activities are motivated by prospective 
benefits from greater market forces and increasing bank efficiency (Miftah \& Wibowo, 2017). Apart from mergers, strategies such as the acquisition of Islamic business units from Islamic banks can improve performance. Merger and acquisition activities will improve the company's performance in the market (Zaharias \& Pradipta, 2016).

Several studies have analyzed the ability of firms to use market power in a statistical framework to investigate the relationship between market concentration and prices (Focarelli \& Panetta, 2003). One consequence of the merger is the growing concern over possible anti-competitive effects (Pana et al., 2010). In fact, the effect of consolidation on market prices is ambiguous. On the one hand, $M \& A$ can increase efficiency, enable economies of scale, synergies, and better asset management. On the other hand, if the merging firms have overlapping local markets, their market power may increase. If the efficiency effect dominates, the merger will lower costs and lower consumer prices. However, if the increase in market power is dominant, the agreement will result in higher prices (Focarelli \& Panetta, 2003).

The fact that the combined firms can become more efficient does not mean that efficiency gains will be passed on to consumers through lower prices. In fact, consolidation can increase market power, leading to higher prices and lower levels of activity (Kemal, 2011). The effect of a merger on price depends on several factors, such as the characteristics of the agreement (for example inside the market or outside the market), the ease of entry of the market by potential competitors, the geographic scope of the markets involved both locally, nationally and internationally. Hence, there is ambiguity depending on whether market forces or efficiency effects prevail.

From the perspective of bank customers, the important point is whether this efficiency causes price changes that benefit consumers or not. In the framework of the Farrell-Shapiro model, a sufficient (and natural) condition for a change in price that is favorable to consumers is that the marginal costs of firms that are aggregated at the pre-amalgamation of the firms that merge are below the marginal costs of the more efficient firms (Egger \& Hahn, 2010). This means that there must be postmerger synergies such as the scale and/or scope of the economy in order to produce price changes that are beneficial to bank customers, thereby improving consumer welfare (Goyal \& Joshi, 2011).

\section{CONCLUSION}

Although Islamic banking continues to increase every year, its growth rate shows a downward trend, so the ratio of assets of Islamic banking compared to national banking is still low with a percentage of less than $5 \%$ a year. In addition, the market share of Indonesian Islamic banking is still very low which is only $6.18 \%$, which means that $93.82 \%$ of the national banking market is still held firmly by conventional banks. Therefore, a merger strategy is needed as a step to strengthen and accelerate

Published by University of Airlangga.

This is an open access article under the CC BY license (https://creativecommons.org/licenses/by-nc-sa/4.0/) 
the growth of Islamic banking in Indonesia in order to be able to achieve the mission in which Indonesia becomes the world's center of Islamic finance. Islamic bank mergers are believed to be a value creation strategy, increasing efficiency for the sake of generating profits by increasing resource allocation rather than reducing costs to increase the market share. Islamic banks will benefit from a consolidation or merger in several ways. First, Islamic financial institutions can expand the scope of their products and services. Second, Islamic financial institutions can gain efficiency through diversification and improving management quality. Third, through the merger of Islamic banking, it is possible to unify various banking resources, including financial and human resources to improve their financial performance. Other impacts that can be obtained are more efficient pricing due to lower operating costs and market expansion, which is expected to have a positive impact on customers.

Even though this research has encountered many obstacles due to limited references and topics of study that have not been widely discussed, considering that the merger of Islamic banks in Indonesia is still in its early stages. Therefore, it is hoped that in the future there will be further research that measures the impact of the post-merger of Islamic banking into Indonesian Sharia Bank (BSI) by using financial performance indicators and market share developments. In addition, this research is expected to have implications for the development of insights and strategy determination in order to increase the future growth of the Islamic economy in Indonesia, primarily related to the banking merger strategy.

\section{ACKNOWLEDGMENT}

It is incomplete if the author does not express his sincere gratitude to the various parties who have helped us in completing this journal, therefore through this introductory, we would like to say Jazaakumullahu Khairan (may Allah SWT reward him with something much better) to JEBIS: Journal of Islamic Economics and Business. Our gratitude goes to all parties who have helped with this journal. With this journal it is hoped that it can become an additional literature for further researchers regarding the potential development of Islamic banking after the merger as an effort to strengthen the inclusion and acceleration of Islamic finance in Indonesia.

\section{REFERENCES}

Ahdizia, K., Masyita, D., \& Sutisna, S. (2018). Business Valuation of Islamic Banks in Merger Plan To Become An Indonesia's State-Owned Islamic Bank. Etikonomi, 17(2), 223-236. https://doi.org/10.15408/etk.v17i2.7238

Al-Hroot, Y. A., Al-Qudah, L. A., \& Alkharabsha, F. I. (2020). The Impact of Horizontal Mergers on The Performance of The Jordanian Banking Sector. Journal of Asian Finance, Economics and Business, 7(7), 49-58. https://doi.org/10.13106/jafeb.2020.vol7.no7.049

Al-Sharkas, A. A., Hassan, M. K., \& Lawrence, S. (2007). The Impact of Mergers and Acquisitions on The Efficiency of The US Banking Industry: Further Evidence. 
Journal of Business Finance and Accounting, 35(1-2), 50-70.

https://doi.org/10.1111/j.1468-5957.2007.02059.x

Alharbi, A. (2015). Development of the Islamic Banking System. Journal of Islamic Banking and Finance, 3(1), 12-25. https://doi.org/10.15640/jibf.v3n1a2

Ascarya, A., \& Yumanita, D. (2005). Bank Syariah: Gambaran Umum. Pusat Pendidikan dan Studi Kebanksentralan (PPSK) Bank Indonesia.

Balqis, M. U., \& Sahar, J. (2019). Pengalaman Lansia dengan Demensia Ringan-Sedang dalam Melakukan Komunikasi dengan Pelaku Rawat: Systematic Review. Jurnal Endurance: Kajian Jurnal IImiah Problema Kesehatan, 4(2). http://ejournal.Ildikti10.id/index.php/endurance/article/view/4046

Bank Indonesia. (2018). STRATEGI, KEBIJAKAN \& PROGRAM PENGEMBANGAN EKONOMI DAN KEUANGAN SYARIAH. Bank Indonesia.

Berger, A. N., \& DeYoung, R. (2001). The Effects of Geographic Expansion on Bank Efficiency. Journal of Financial Services Research, 19, 163-184. https://doi.org/10.1023/A:1011159405433

Berger, A. N., \& Humphrey, D. B. (1992). Megamergers in Banking and the Use of Cost Efficiency as Antitrust Defense. The Antitrust Bulletin, 37(4), 541-600. https://doi.org/10.1177/0003603X9203700302

Brewer, E., Jackson, W. E., \& Jagtiani, J. (2000). Impact of Independent Directors and the Regulatory Environment on Bank Merger Prices: Evidence from Takeover Activity in the 1990s. In Federal Reserve Bank of Chicago. https://doi.org/10.2139/ssrn.256990

Calomiris, C. W., \& Karceski, J. (2000). Is the Bank Merger Wave of the 1990s Efficient? Lessons from Nine Case Studies. In Steven N. Kaplan. University of Chicago Press.

Carletti, E., Hartmann, P., \& Onega, S. (2008). The Economic Impact of Merger Control Legislation. In CFS Working Paper Series (Issue 4).

Carletti, E., Hartmann, P., \& Ongena, S. (2007). The economic impact of merger control: what is special about banking? In ECB Working Paper (Issue 786). https://papers.ssrn.com/sol3/papers.cfm?abstract_id=1001451

Clarke, N., \& Salleh, N. M. (2011). Emotions and Their Management during a Merger in Brunei. Human Resource Development International, 14(3), 291-304. https://doi.org/10.1080/13678868.2011.585064

CNBC Indonesia. (2020). Siap Direalisasikan, Ini Target Merger Bank Syariah BUMN. CNBC Indonesia TV. https://www.cnbcindonesia.com/market/20201013154134-19-194015/siapdirealisasikan-ini-target-merger-bank-syariah-bumn

Degryse, H., Nancy, M., \& Mitchell, J. (2004). SMEs and Bank Lending Relationships: The Impact of Mergers. In National Bank of Belgium Working Paper (Vol. 46). https://doi.org/10.2139/ssrn.1691599

Egger, P., \& Hahn, F. R. (2010). Endogenous Bank Mergers and Their Impact on Banking Performance: Some Evidence from Austria. International Journal of Industrial Organization, 28(2), 155-166. https://doi.org/10.1016/j.ijindorg.2009.07.007

Elnahas, A., Hassan, M. K., \& Ismail, G. (2017). Religion and Mergers and Acquisitions Contracting: The Case of Earnout Agreements. In Journal of Corporate 
Finance, Forthcoming. https://doi.org/10.2139/ssrn.2800794

Fahim, F., Wajidi, F. A., Abid, S., \& Rehan, E. W. (2017). Potential of Islamic Finance in Growth of Pakistan Economy. International Journal of Economics, Commerce and Management, $V(2), 403-435$.

Financial Service Authority. (2017). Laporan Perkembangan Keuangan Syariah Indonesia Tahun 2017. Financial Service. https://www.ojk.go.id/id/berita-dankegiatan/publikasi/Documents/Pages/Laporan-Perkembangan-KeuanganSyariah-2017/Laporan Perkembangan Keuangan Syariah Indonesia (LPKSI) 2017 (final).pdf

Financial Service Authority. (2019). Statistik Perbankan Syariah 2020. In Financial Service Authority.

Focarelli, D., \& Panetta, F. (2003). Are Mergers Benefical to Consumers? Evidence from The Market for Bank Deposits. American Economic Review, 93(4), 11521172. https://doi.org/10.1257/000282803769206241

Ghosh, A., \& Jain, P. C. (2000). Financial Leverage Changes Associated with Corporate Mergers. Journal of Corporate Finance, 6(4), 377-402. https://doi.org/10.1016/S0929-1199(00)00007-9

Gitman, L. J., \& Zuter, C. (2011). Principles of Managerial Finance (13th ed.). Prentice Hall.

Goyal, K. A., \& Joshi, V. (2012). Mergers in Banking Industry of India: Some Emerging Issues. Asian Journal of Business and Management Sciences, 1(2), 157-165.

Goyal, Krishn A., \& Joshi, V. (2011). Impact of Merger on Stress Level of Employees (A Case Study of Erstwhile Bank of Rajasthan Ltd.). International Journal of Business Research and Management (IJBRM), 3(5), 234-248.

Gupitasari, N., Setyowati, R., \& Muhyidin, M. (2016). MEKANISME KONSOLIDASI BANK SYARIAH ANAK PERUSAHAAN BADAN USAHA MILIK NEGARA (BUMN) DARI PERSPEKTIF YURIDIS. Diponegoro Law Journal, 5(3), 1-22. https://ejournal3.undip.ac.id/index.php/dlr/article/view/12131

Haynes, M., \& Thompson, S. (1999). The productivity effects of bank mergers: Evidence. Journal of Banking \& Finance, 23(5), 825-846. https://doi.org/10.1016/S0378-4266(98)00117-4

Healy, P. M., Palepu, K. G., \& Ruback, R. S. (1992). Does Corporate Performance Improve after Mergers? Journal of Financial Economics, 31(2), 135-175. https://doi.org/10.1016/0304-405X(92)90002-F

Hendriana, N. G. (2012). Analisis Perkembangan dan Prediksi Tingkat Pertumbuhan Bank Syariah di Indonesia [UIN Syarif Hidayatullah Jakarta]. http://repository.uinjkt.ac.id/dspace/handle/123456789/246

Islamic Finance Country Index. (2020). Islamic Finance Country Index-IFCI 2019. In Global Islamic Finance Report 2019. http://www.gifr.net/publications/gifr2019/ifci.pdf

Ismariyah. (2007). Merger Bank dalam Tinjauan Hukum Islam (Kasus Merger Bank Mandiri). Jurnal Hukum Islam, 4(2), 1.

Jayaratne, J., \& Strahan, P. E. (1997). The Benefits of Branching Deregulation. Economic Policy Review, 3(4), 13-29.

Karceski, J., Ongena, S., \& Smith, D. C. (2005). The Impact of Bank Consolidation on Commercial Borrower Welfare. The Journal of Finance, 60(4), 2043-2082. https://doi.org/10.1111/j.1540-6261.2005.00787.x 
Kemal, M. U. (2011). Post-Merger Profitability : A Case of Royal Bank of Scotland ( RBS ). International Journal of Business and Social Science, 2(5), 157-162.

Kimie, H., \& Takatoshi, I. (2008). Did Mergers Help Japanase Mega-Banks Avoid Failure? : Analysis of the Distance to Default of Banks. Journal of The Japanese and International Econimies, 25(1), 1-22. https://doi.org/10.1016/j.jjie.2010.09.001

Komite Nasional Keuangan Syariah. (2019). Kajian Konversi Merger Holding dan Pembentukan Bank BUMN Syariah. Komite Nasional Keuangan Syariah.

Komite Nasional Keuangan Syariah. (2020, January). Trend Konversi ke Bank Syariah: Tingkatkan Efisiensi dan Produktivitas Bisnis. Insight Buletin Ekonomi Syariah, Januari 20(8), 1-11.

Long, P. H. (2015). Merger and Acquisitions in the Czech Banking Sector-Impact of Bank Mergers on the Efficiency of Banks. Journal of Advanced Management Science, 3(2), 86-92. https://doi.org/10.12720/joams.3.2.86-92

Marimin, A., \& Romdhoni, A. H. (2017). Perkembangan Bank Syariah di Indonesia. Jurnal Ilmiah Ekonomi Islam, 1(02), 75-87. https://doi.org/10.29040/jiei.v1i02.30

Miftah, K., \& Wibowo, H. (2017). Merger and Industrial Acceleration: Study at Indonesian Islamic Banking Industry. Signifikan: Jurnal IImu Ekonomi, 6(1), 2948. https://doi.org/10.15408/sjie.v6i1.4728

Montoriol-Gariga, J. (2008). Bank Mergers and Lending Relationships. In ECB Working Paper No. 934.

Nizar, M. A., \& Nasir, M. (2016a). Akselerasi dan Inklusivitas Sektor Keuangan : Jalan Menuju Kesejahteraan Rakyat. In Naga Media.

Nizar, M. A., \& Nasir, M. (2016b). Strengthening Sharia Banking through Merger or Consolidation. In Akselerasi dan Inklusivita Sektor Keuangan: Jalan Menuju Kesejahteraan Rakyat. Naga Media.

Pana, E., Park, J., \& Query, T. (2010). The Impact of Bank Mergers on Liquidity Creation. Journal of Risk Management in Financial Institutions, 4(1), 74-96.

Prihartono, A. (2018). Pengaturan Penggabungan Usaha (Merger Bank sebagai Upaya Peningkatan Kesehatan Bank di Indonesia dalam Pembangunan Hukum Ekonomi Nasional. AKTUALITA, 1(1), 1-15.

Sari, M. D., Bahari, Z., \& Hamat, Z. (2013). Perkembangan Perbankan Syariah di Indonesia: Suatu Tinjauan. Jurnal Aplikasi Bisnis, 3(2), 120-138. https://www.researchgate.net/publication/304777260_PERKEMBANGAN_PE RBANKAN_SYARIAH_DI_INDONESIA_SUATU_TINJAUAN

Sherman, H. D., \& Rupert, T. J. (2006). Do Bank Mergers Have Hidden or Foregone Value? Realized and Unrealized Operating Synergies in One Bank Merger. European Journal of Operational Research, 168(1), 253-268. https://doi.org/10.1016/j.ejor.2004.05.002

Sufian, F. (2007). The Efficiency of Islamic Banking Industry: a Non-Parametric Analysis With Non-Discretionary Input Variable. Islamic Economic Studies, 14(1), 54-87. https://papers.ssrn.com/sol3/papers.cfm?abstract_id=3161398

Suhendro, D. (2018). Tinjauan Perkembangan dan Pertumbuhan Perbankan Syariah di Indonesia. Human Falah: Jurnal Ekonomi Dan Bisnis Islam, 5(2), 211-227. http://jurnal.uinsu.ac.id/index.php/humanfalah/article/view/1736 
Syukron, A. (2013). Dinamika Perkembangan Perbankan Syariah di Indonesia. Economic: Jurnal Ekonomi Dan Hukum Islam, 3(2), 28-53.

http://ejournal.kopertais4.or.id/tapalkuda/index.php/economic/article/view/ 785

Vallascas, F., \& Hagendorff, J. (2011). The Impact of European Bank Mergers on Bidder Default Risk. Journal of Banking and Finance, 35(4), 902-915. https://doi.org/10.1016/j.jbankfin.2010.09.001

Yudistira, D. (2004). Efficiency in Islamic Banking: An Empirical Analysis of Eighteen Banks. Islamic Economic Studies, 12(1). https://ssrn.com/abstract=3164166

Zaharias, B. M., \& Pradipta, H. (2016). Penaksiran Dampak Merger dan Akuisisi terhadap Efisiensi Perbankan, Analisis Sebelum dan Setelah Merger dan Akuisisi. Jurnal Ekonomi Dan Pembangunan, 24(2), 85-95.

https://www.jurnalekonomi.lipi.go.id/index.php/JEP/article/view/109

Zubair, M. K. (2008). Akselerasi Pertumbuhan Bank Syariah di Indonesia. Millah:

Jurnal Studi Agama, 8(1), 2008. https://doi.org/10.20885/millah.vol8.iss1.art1 